\title{
Molecular analysis of 20 patients with 2 q37.3 monosomy: definition of minimum deletion intervals for key phenotypes
}

\author{
M A Aldred, R O C Sanford, N S Thomas, M A Barrow, L C Wilson, L A Brueton, M C Bonaglia, \\ R C M Hennekam, C Eng, N R Dennis, R C Trembath
}

J Med Genet 2004;41:433-439. doi: 10.1136/jmg.2003.017202

$\mathrm{T}$ erminal deletions of the long arm of chromosome 2 (2q37) have been recorded in the literature for more than a decade and an associated syndrome first became apparent when nine patients were reported with an Albright hereditary osteodystrophy (AHO)-like metacarpal/ metatarsal shortening (brachymetaphalangism). ${ }^{12}$ This is also known as brachydactyly-mental retardation syndrome (BDMR, MIM 600430). To date, some 60 or so cases of $2 \mathrm{q} 37$ deletion or monosomy resulting from unbalanced translocations have been reported. Significant variability in clinical presentation is apparent, but almost all patients have some degree of mental retardation and facial dysmorphism. Brachymetaphalangism has been reported in approximately $50 \%$ of cases. ${ }^{1-15}$ Congenital heart anomalies are present in around $20 \%$ of patients with $2 \mathrm{q} 37$ monosomy, ${ }^{16-22}$ compared to $1 \%$ of the general population. These are predominantly atrial or ventricular septal defects, but more complex problems have been reported. ${ }^{17}{ }^{22}$ Additionally, there are two reports of tetralogy of Fallot with monosomy 2q37 resulting from unbalanced translocations, ${ }^{23}{ }^{24}$ but both cases were also trisomic for $17 \mathrm{q} 25$ and it is not clear which imbalance was causative. Other phenotypes repeatedly associated with 2q37 deletions include Wilms tumor and urogenital anomalies, ${ }^{6} 1719$ epilepsy, ${ }^{12}$ 7-9 $14162025-27$ eczema, ${ }^{25-7} 162829$ and autism or repetitive, hyperkinetic

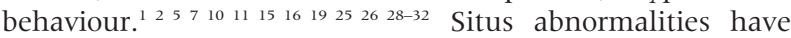
been reported in two cases ${ }^{9}$ and holoprosencephaly in one infant. ${ }^{33}$

Most 2q37 rearrangements reported to date have been only minimally characterised by conventional cytogenetics or subtelomeric fluorescent in situ hybridisation (FISH). A small number have been subjected to more detailed analysis using multiple FISH clones or microsatellite markers, ${ }^{2}{ }^{10} 1526$ but the ability to assign breakpoints and make genotypephenotype correlations has been limited. We therefore sought to conduct detailed molecular analyses of a panel of $2 \mathrm{q} 37$ deletion patients, focusing on the critical interval distal to $\mathrm{D} 2 \mathrm{~S} 338^{2}$ and including assessment of individual gene dosage by multiplex amplifiable probe hybridisation (MAPH). ${ }^{34}$ We define minimal deletion intervals for all of the major phenotypes associated with 2q37 monosomy.

\section{METHODS}

This study has been approved by the Leicestershire ethics committee. Seven patients have been described previously. ${ }^{271626}$ Thirteen additional patients with known 2 q37 rearrangements were ascertained through clinical genetics departments in the UK and clinical details are provided as supplementary online information at http:// jmg.bmjjournals.com/supplemental/. Informed consent was obtained from parents or guardians. The patient panel comprised 16 deletions, two inverted duplication/deletions, one ring chromosome and one unbalanced translocation. The ring chromosome (patient 53) has virtually no loss of $2 p$

\section{Key points}

- We have conducted detailed dosimetric analysis in 20 patients with monosomy $2 q 37$.

- No common breakpoints were found, indicating that 2q37 rearrangements are likely not mediated by duplicated low copy repeats.

- The minimum deleted region in patients with characteristic facial dysmorphism and Albright hereditary osteodystrophy (AHO)-like brachymetaphalangism has been narrowed to approximately $3 \mathrm{Mb}$.

- For the first time, preliminary assignments of critical intervals for other features of the syndrome have now been made. All such intervals share a $1.5 \mathrm{Mb}$ overlap.

- However, considerable clinical variability was apparent and no clear genotype-phenotype correlations could be drawn that would help predict clinical prognosis in a newly-diagnosed young proband.

material, being heterozygous for microsatellite D2S2584, $\sim 160 \mathrm{~kb}$ from the telomere, and retaining the $2 \mathrm{p}$ subtelomeric FISH probe 2052f6. The phenotype is therefore presumed to be due solely to the 2 q 37 deletion.

DNA was extracted from peripheral blood leukocytes or buccal cells using standard methods. MAPH was conducted essentially as described, ${ }^{34}{ }^{35}$ except that probes were cloned into pCR2.1-TOPO using the TOPO-TA cloning kit (Invitrogen, Paisley, UK) and the sequence of the blocking primers was modified accordingly. Probes were designed to the following 2q37 genes: RDC1, RAMPI, ILKAP, MIP-T3, ASB1, TWIST2, HDAC4, NDUFA10, HDLBP, ATSV, GP3ST, PASK, PPP1R7, FARP2, STK25, NEDD5, DTYMK, and to unique sequence adjacent to the polymorphic markers D2S125, D2S140, D2S2585 (2qTEL44), D2S2985 (2qTEL37) and D2S2986 (2qTEL47). Details of probe sequences are available on request. Probes were organised into two multiplex sets for patient analysis and were first tested on DNA from a patient with a large deletion and normal controls to verify their quantitative performance. Results for selected genes were also verified by realtime quantitative PCR (data not shown).

In some cases it was not possible to perform MAPH, as only small quantities of DNA were available from buccal swab samples. We therefore designed 11 new microsatellite markers, spanning the region from immediately proximal to HDAC4 (BAC AC114788) to the telomere, by in silico

Abbreviations: $\mathrm{AHO}$, Albright hereditary osteodystrophy; BDMR, brachydactyly-mental retardation syndrome; FISH, fluorescent in situ hybridisation; MAPH, multiplex amplifiable probe hybridisation; OR, olfactory receptor 
screening of publicly-available BAC sequence using the Tandem Repeats Finder program. ${ }^{36}$ Primer sequences and annealing temperatures are shown in table 1. All new markers proved to be polymorphic. Existing microsatellite markers from the Genethon and Marshfield genetic maps were analysed using primers available from the public genome databases. Singleplex reactions were conducted for 40 cycles using HotStar PCR mastermix (Qiagen, Crawley, UK) supplemented with $1 \times$ Q-solution. Multiplex reactions utilised the Multiplex PCR Mastermix (Qiagen, Crawley, UK) supplemented with $0.5 \times$ Q-solution, also for 40 cycles following the manufacturer's recommended thermocycle profile. All microsatellites were labelled with 6-FAM, HEX, or TET fluorophores and analysed on an ABI377 $12 \mathrm{~cm}$ genotyping gel.

\section{RESULTS}

\section{Clinical characteristics}

Clinical features for all cases are summarised in table 2 . Consistent with the literature, all except the very youngest patient had mild or moderate developmental delay and some degree of facial dysmorphism. Consent for publication of facial photographs was given in four cases (fig 1) and a further five were published previously (patients 75, 76, 10780, 419 and 622). ${ }^{24716}$ Common features include round face with flattened nasal bridge, frontal bossing, deep-set eyes, up-slanting palpebral fissures, anteverted nares, and thin upper lip. In contrast, the facial dysmorphism in patient 63 was markedly different (see online supplementary information), consistent with her duplication for much of 2q37 and only a very small telomeric deletion (see molecular results below). AHO-like brachymetaphalangism was observed in $11(55 \%)$ of our patients, autism or repetitive, hyperkinetic behaviours in seven (35\%), non-febrile seizures also in seven $(35 \%)$, eczema in five $(25 \%)$, and heart abnormalities in four $(20 \%)$. These frequencies are in keeping with those in the wider literature, with the exception of epilepsy, which has been reported in about one-quarter of patients overall. Frequencies for brachymetaphalangism and autism may be underestimates, since some patients, both in this series and the wider literature, are too young to manifest these phenotypes, while eczema might be overlooked unless severe. There was a marked excess of females in our series, but this is much less apparent in the literature as a whole.

\section{Molecular characteristics}

Molecular results are summarised in fig 2. Parental samples were available in 16 of the 19 non-familial cases. All 16 were shown to be de novo rearrangements, none showed coexistence with the known 2q subtelomeric polymorphism ${ }^{37} 38$
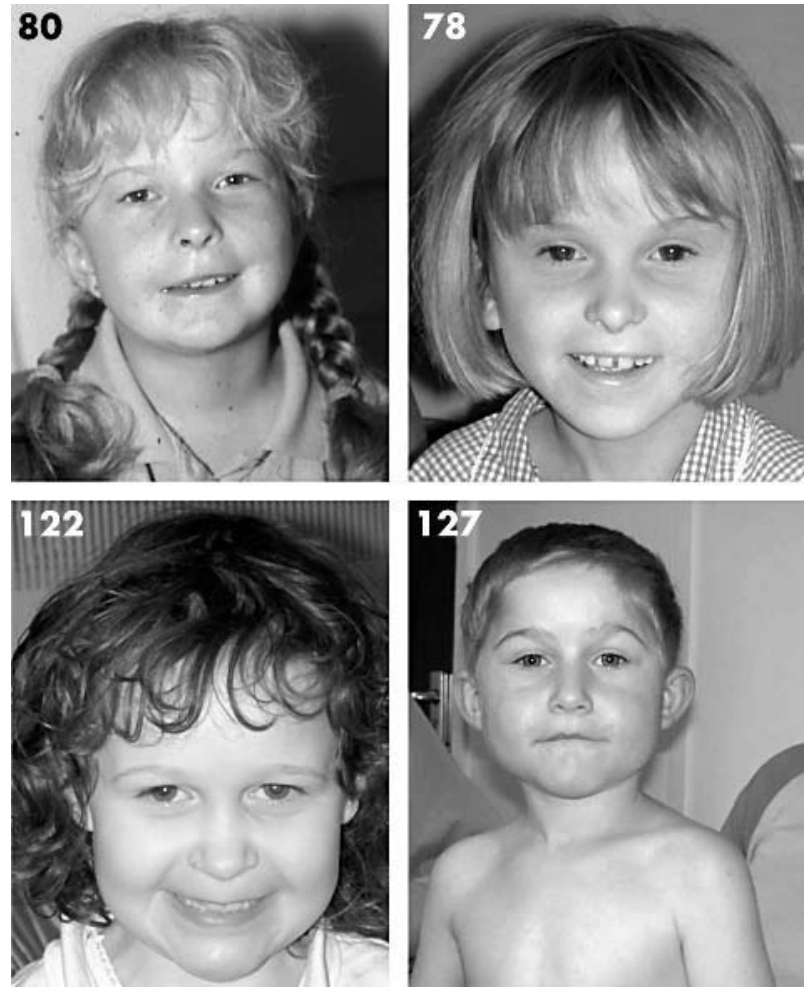

Figure 1 Photographs of four patients with $2 q 37$ deletion illustrate the typical facial appearance in this syndrome.

and approximately equal proportions of paternally and maternally-derived rearrangements were observed. A similar lack of bias in parental origin is seen in Williams-Beuren, DiGeorge, and 18p- syndromes, ${ }^{39-41}$ whereas Sotos, WolfHirschhorn, Cri-du-chat, and 18q- syndromes are predominantly paternal in origin ${ }^{42-45}$ and 1 p36 deletions show a slight maternal bias. ${ }^{46}$

As suggested by the original cytogenetic analyses, all patients were found to have terminal deletions with the exception of patient 75 (AW, Fisher $e t \mathrm{al}^{16}$ ), who showed an interstitial deletion with the distal breakpoint localised between D2S140 (deleted) and AC005237CA (retained). Microsatellite analysis in patient 63 showed that the inverted duplication detected cytogenetically was accompanied by a previously undetected small terminal deletion. The duplicated and deleted regions were apparently separated by a small region of normal gene dosage, as judged by relative

Table 1 Primer sequences for SNPs and microsatellites

\begin{tabular}{|c|c|c|c|c|}
\hline Marker & Forward primer & Reverse primer & Size (bp) & $\begin{array}{l}\text { Annealing } \\
\text { temperature }\end{array}$ \\
\hline rs3086056 (HES6) & GTTCACTCTGGCTCACCTCAAT & HEX-CCCACTGCCCCAATAGCTC & $95 / 100$ & $55^{\circ} \mathrm{C}$ \\
\hline rs 11165 (TWIST2) & TIACTTCACGCCGCTATTCT & ACGTCTITATIITTCCTGGGTG & T/A SNP & $55^{\circ} \mathrm{C}$ \\
\hline $\mathrm{ACl} 14788 \mathrm{CA}^{*}$ & GTTCTTACTGGGATGCTGAGATATGGAC & FAM-CAAATCCACTTGTTGTCTGGTG & $260-290$ & $62.4^{\circ} \mathrm{C}$ \\
\hline AC017028CA* & HEX-TCAAAGTGCGCTGAGAGTGG & GTTCTTGTGGACAGATGTGGAAGTAGC & $90-120$ & $62.4^{\circ} \mathrm{C}$ \\
\hline AC062017TG & GCAAAGGTTCATACAGATACCGA & HEX-CTGTCAAAGGAAAAAGGGAAGC & $160-180$ & $55^{\circ} \mathrm{C}$ \\
\hline AC093802CA & GTTCACCAACTCAAATGCTAATCCA & HEX-CAACATCAGTGTAACCATAAAACA & $170-190$ & $52^{\circ} \mathrm{C}$ \\
\hline АС093802TTAT & FAM-TCACTCATCTITGCCTGGATAG & TTCATATTTACACGTAGAAGACGG & $230-250+$ & $55^{\circ} \mathrm{C}$ \\
\hline $\mathrm{AC} 13469 \mathrm{CA}^{*}$ & GTTCTTATCCTATGGAACACCTCTCCC & HEX-AATTCATCTGACCAAGCATGTG & $230-250$ & $62.4^{\circ} \mathrm{C}$ \\
\hline $\mathrm{AC} 124862 \mathrm{CA}$ & GACGCATCACTCTACCTAAAAAAA & HEX-CAATGCAGGTCTAAATGACCAG & $100-120$ & $55^{\circ} \mathrm{C}$ \\
\hline AC005237CA* & FAM-ATCAGCTACTGTCAATTCATTCG & GITCACCCCTACTCCCAGAAGTCC & $80-120$ & $62.4^{\circ} \mathrm{C}$ \\
\hline AC005104CA* & GTTCTTATACATGCACACACGACCACA & TET-GAACAAAGAACTGGACCCTCAG & $115-149$ & $62.4^{\circ} \mathrm{C}$ \\
\hline AC093642CA* & GTICTTGCAGTTAATCTTGACACATCA & FAM-GGGAACAAAAAGAAGGCATGTA & $150-170$ & $62.4^{\circ} \mathrm{C}$ \\
\hline AC131097CA* & FAM-GTTAAGGGGCTGGACGGG & GTTTCTTAGTCTCCTCGCTCGTGGC & $200-220$ & $62.4^{\circ} \mathrm{C}$ \\
\hline
\end{tabular}

*These markers were amplified as one multiplex PCR, as described in Methods; ffragment is $\sim 520 \mathrm{bp}$ in length and was digested with Hpall prior to analysis on ABI377. 


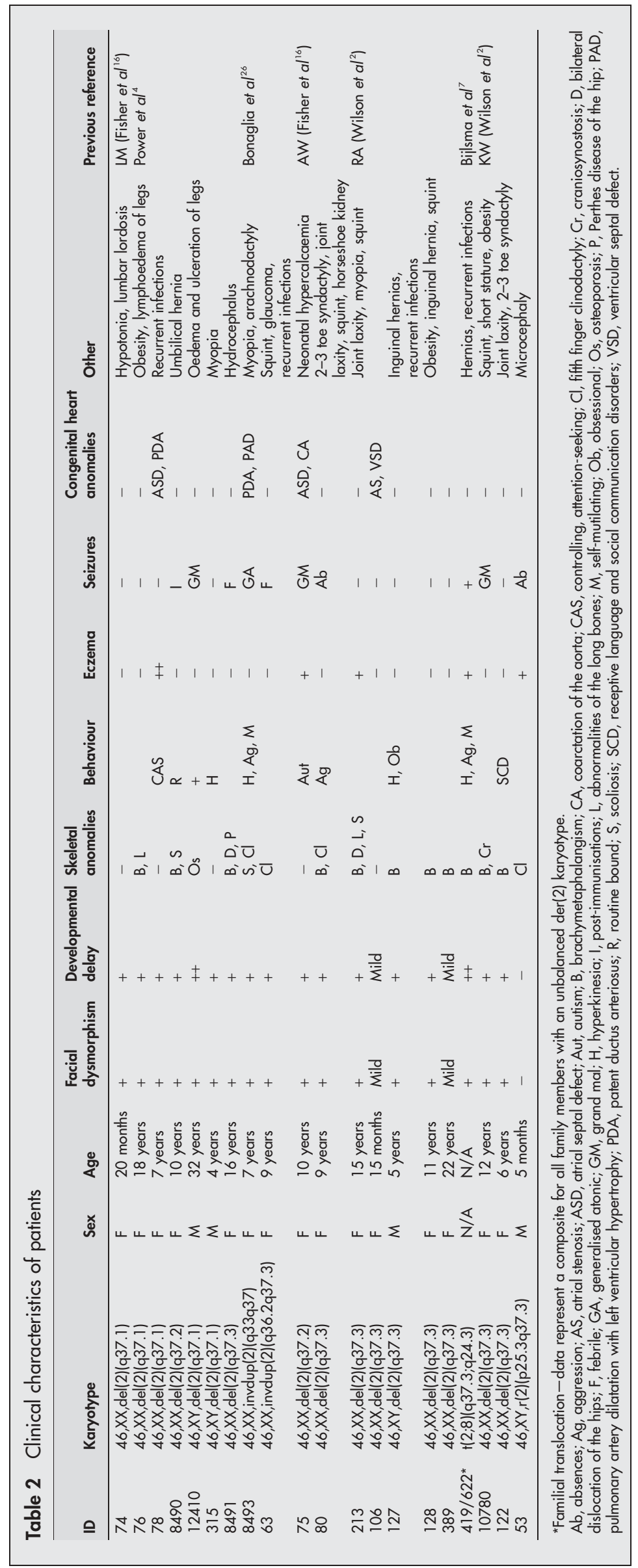




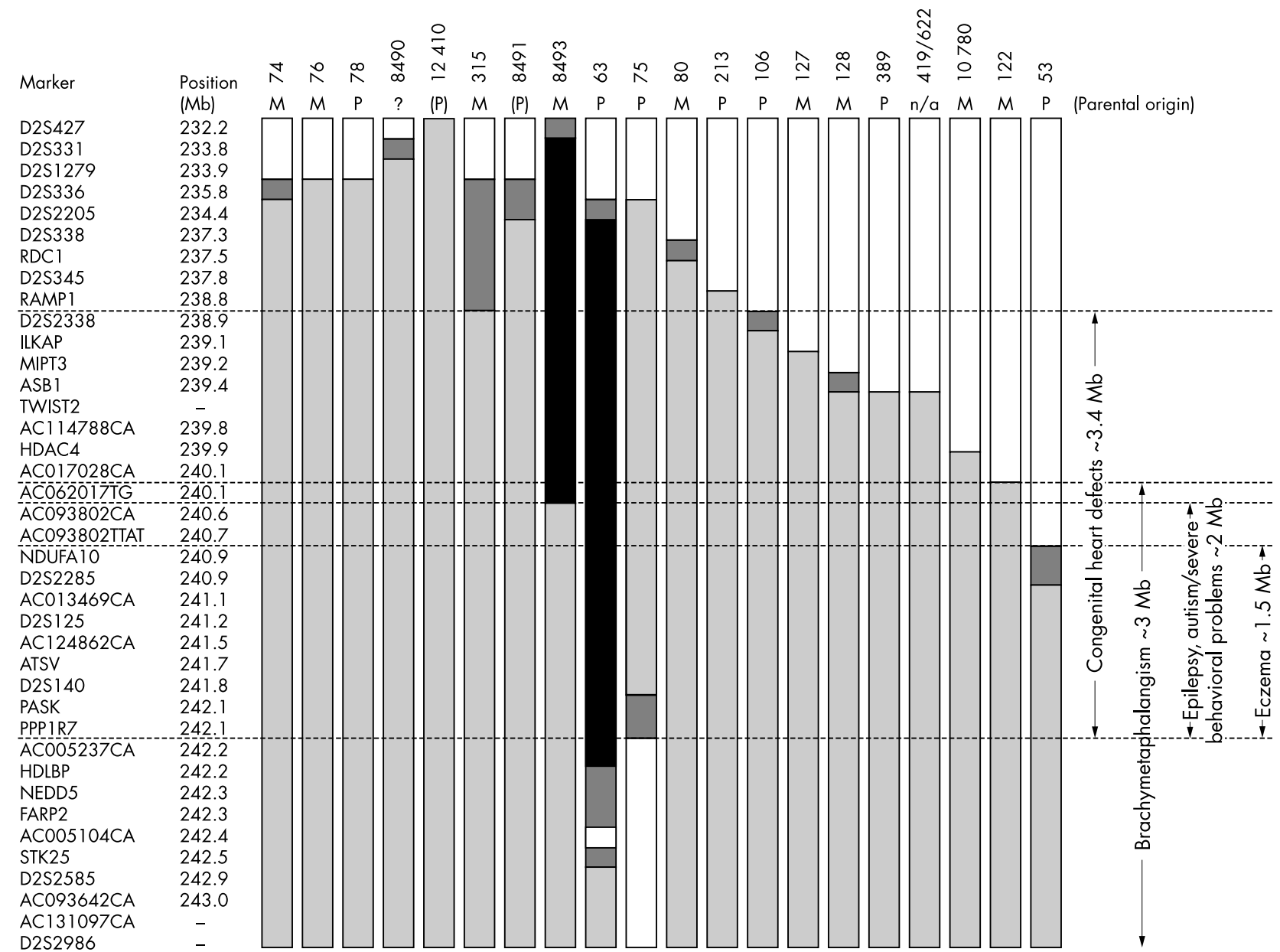

Figure 2 Results and definition of minimal deletion intervals. Positions of markers are those from Ensembl genome assembly release 17.33.1 M, maternal; $\mathrm{P}$, paternal; $(\mathrm{P})$, assumed paternal origin, as patient and mother had one allele in common for every microsatellite tested but paternal sample was not available; $\mathrm{n} / \mathrm{a}$, not applicable to familial translocation; white shading, normal dosage; black shading, duplicated; grey shading, deleted; hatched shading, uninformative or not tested.

peak heights of the microsatellites. This has not yet been verified by alternative methods, but would be in keeping with the mechanism proposed by Bonaglia et $a l^{26}$ for the causation of inverted duplications.

\section{Breakpoint mapping and minimum deletion intervals} Since we wished to focus on the critical interval for AHO-like phenotype, distal to D2S338, breakpoints in the larger deletions were not characterised in detail. Breakpoints in the nine smallest terminal deletions, the translocation, and one duplication/deletion all localised within a $3.8 \mathrm{Mb}$ region bounded by D2S338 proximally and AC013469CA distally. Two of these breakpoints, patients 10780 and 122, were precisely localised to non-overlapping intervals of 169 and $33.8 \mathrm{~kb}$, respectively, within the HDAC4 gene. Taken as a whole, these data define the most distal breakpoints so far characterised for both interstitial and terminal 2q37 deletions.

We then attempted to define the minimal deleted interval for each of the major features of the syndrome (fig 2). Due to the apparent reduced penetrance, this was done on an inclusion-only basis, that is, the absence of a clinical characteristic was not used as a criterion for excluding that genomic region. The critical interval for the AHO-like brachymetaphalangism extends from HDAC4 to the telomere, a region of approximately $3 \mathrm{Mb}$, as defined by patients 10780 and 122. These patients also both show the characteristic facial dysmorphism. The interstitial nature of the deletion in patient 75, who clinically showed an atrial septal defect, eczema, epilepsy, and autism, ${ }^{16}$ potentially excludes a number of the most telomeric $2 \mathrm{q}$ genes as candidates for these phenotypes. Thus, the minimum deleted region amongst our patients with autistic or hyperkinetic behaviour and/or epilepsy is $\sim 2.1 \mathrm{Mb}$ between HDAC4 and AC005237CA. An overlapping $1.5 \mathrm{Mb}$ region is deleted in patients with eczema, while RAMPI and AC005237CA bound a $\sim 3.4 \mathrm{Mb}$ region common to patients with cardiac septal defects (fig 2).

\section{DISCUSSION}

Genotype-phenotype correlations have been instructive in a number of other deletion syndromes to define discrete clinical subgroups, leading to more accurate prognostication and identification of candidate genes for specific phenotypes. ${ }^{44}{ }^{46-50}$ In conducting this detailed analysis of 20 patients with 2 q37 rearrangements, our aims were threefold: (a) to refine the minimal deleted region for the AHO-like brachymetaphalangism; (b) to determine whether genotypephenotype correlations could be drawn for other features of the syndrome; and (c) to precisely map the breakpoints as possible clues to the rearrangement mechanism.

\section{Brachymetaphalangism}

The critical interval for the AHO-like brachymetaphalangism is unequivocally assigned to the $3 \mathrm{Mb}$ region from HDAC4 to 
the telomere. This represents a refinement of approximately $2 \mathrm{Mb}$ compared to the previous minimum interval. ${ }^{15}$ It has previously been suggested that much of this interval could be excluded due to arachnodactyly in patient 8493. ${ }^{26}$ However, the duplicated region in this patient extends just proximal of the Indian hedgehog gene $(I H H)$. Mutations of $I H H$ are now known to cause brachydactyly type A. ${ }^{51}$ Therefore, duplication of the gene might result in the reverse phenotype, unusually long fingers, which would account for the arachnodactyly phenotype in this patient and would likely override any subtle abnormality due to the terminal $2 \mathrm{q}$ deletion. Three genes previously proposed as candidates for the brachymetaphalangism phenotype, GPCl, $H D L B P$, and $S T K 25,{ }^{10} 1252$ are localised within the $3 \mathrm{Mb}$ minimal region and remain candidates. Conversely, TWIST2, which we considered a candidate gene on the basis of its proposed role in regulating osteoblast development, ${ }^{53}$ is not deleted in patient 10780 and can therefore be excluded. Brachymetaphalangism is partially penetrant and is present in approximately half of the patients deleted for this minimum region. Some patients show additional, more serious, skeletal abnormalities but, due to the small number characterised to date, it is unclear whether these represent pleiotropic effects of the same underlying gene.

\section{Additional clinical features}

Several other features of $2 \mathrm{q} 37$ deletions, such as congenital heart anomalies, eczema, autism, and epilepsy, have potentially greater morbidity and thus are clinically more significant. We therefore sought to make genotype-phenotype correlations and investigate whether these are discrete features of a contiguous gene deletion syndrome or pleiotropic effects of haplo-insufficiency for a single gene. Minimum intervals, ranging from 1.5 to $3.4 \mathrm{Mb}$, could be defined for each of these features. However, these phenotypes are less specific than brachymetaphalangism and, being more common in the general population, phenocopies will also exist. Thus, our assignment of critical intervals for these phenotypes, which is based on a small number of patients, should be regarded as preliminary and requires verification in a larger panel of patients. Some additional support for an autism susceptibility locus at 2 q37.3 is already available from a small terminal deletion in a patient with isolated autism ${ }^{32}$ and from a weak suggestion of linkage in one genome scan. ${ }^{54}$ As presently defined, all minimum intervals share a $1.5 \mathrm{Mb}$ region of overlap. Thus it remains to be determined whether the $2 \mathrm{q} 37$ deletion phenotype represents a contiguous gene deletion syndrome and it is possible that developmental abnormalities of several organ systems might result from haplo-insufficiency of a single gene.

\section{Genotype-phenotype correlations}

Amongst this panel of 2 q37 deletion patients, we found no clear relationship between clinical features and the size or position of the monosomic region. Patients with very similar deletion breakpoints showed markedly different phenotypes, for example 10780 and 122 , or 127 and 389. The same is true in translocation families, where individuals with identical 2q37 deletions have been reported with discordant phenotypes. ${ }^{12}{ }^{14}$ This represents a significant challenge in predicting phenotype for this deletion, since the likely clinical outcome in a young proband cannot be determined from the deletion breakpoints. Variable expressivity is common in deletion syndromes and may be due to reduced penetrance of the haplo-insufficient genes, epigenetic factors, modifying effects of other genes, as recently proposed for $V E G F$ and cardiovascular defects in DiGeorge (del22q11) syndrome, ${ }^{55}$ or multigenic inheritance. ${ }^{56}$ An additional factor might be recessive phenotypes that are only uncovered in a minority of deletion patients.

\section{Mechanism of rearrangement}

Elucidating chromosomal breakpoints can provide clues as to the underlying mechanism of rearrangement. Several interstitial deletion syndromes, including Williams-Beuren (7q), Smith-Magenis (17p) and DiGeorge (22q), show clustered breakpoints and are commonly mediated by low copy repeat sequences and inversion polymorphisms. ${ }^{57-59}$ Clusters of olfactory receptor (OR) genes have also been implicated in recurrent rearrangements involving chromosomes $4 \mathrm{p}$ and $8 p .^{6061}$ OR-like genes have also been mapped to $2 \mathrm{q} 37.3$, but they do not co-localise with the deletion breakpoints in our patients. Furthermore, a recent study suggests that duplicated segments are not involved in mediating the majority of terminal deletions and translocations. ${ }^{62}$ Our data, which show a lack of identical breakpoint locations, support this finding.

\section{Summary}

This detailed analysis of 20 patients with 2 q37.3 monosomy has, for the first time, allowed minimal deletion intervals to be defined for all the major phenotypes of the syndrome. However, there is striking phenotypic variability and it is clear that the size and extent of the deleted region cannot be used as a predictor of the likely phenotype in the patient. As increasing numbers of small deletions are detected by more widespread use of subtelomeric FISH, this presents a challenge for clinicians in trying to determine the likely prognosis for a young proband. Ultimately, therefore, the real challenge is to identify not only the gene(s) on $2 \mathrm{q} 37$ responsible for the phenotypes in these patients, but also the modifiers, be they genetic, epigenetic, or environmental, that contribute to the phenotypic variability between patients with similar breakpoints. Only then can we begin to give more precise prognostic information to the parents of a child newly-diagnosed with a 2q37.3 deletion.

\section{ACKNOWLEDGEMENTS}

We are indebted to Patricia Jacobs for forging this collaboration and to the families for their cooperation in this study. We thank Sue Price and Sheila Youings for additional clinical input and sample collection, John Armour for advice in setting up MAPH, the clinical cytogenetics staff in Salisbury, Leicester, Birmingham, and Manchester for their expertise, and Berendine van Zyl for additional mapping work. CE is a Doris Duke Distinguished Clinical Scientist.

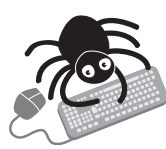

An appendix showing clinical descriptions of previously unpublished patients is available online at http://jmg.bmijournals.com/supplemental/

\footnotetext{
Authors' affiliations

M A Aldred, R C Trembath, Division of Medical Genetics, Departments of Genetics and Cardiovascular Sciences, University of Leicester, Leicester, UK

R O C Sanford, N S Thomas, N R Dennis, Human Genetics Division, University of Southampton, Southampton, UK

R O C Sanford, N S Thomas, Wessex Regional Genetics Laboratory, Salisbury District Hospital, Salisbury, UK

M A Barrow, R C Trembath, Leicestershire Genetics Centre, University Hospitals of Leicester NHS Trust, Leicester, UK

L C Wilson, Clinical and Molecular Genetics Unit, Institute of Child Health and Great Ormond Street Hospital NHS Trust, London, UK L A Brueton, West Midlands Genetics Service, Birmingham Women's Hospital, Birmingham, UK

M C Bonaglia, IRCCS E. Medea, Bosisio Parini, Lecco, Italy

R C M Hennekam, Department of Paediatrics and Clinical Genetics, Academic Medical Centre, Amsterdam, The Netherlands

C Eng, Human Cancer Genetics Program and Division of Human Genetics, The Ohio State University, Columbus, OH, USA
} 
N R Dennis, Wessex Clinical Genetics Service, Princess Anne Hospital, Southampton, UK

This work was supported by the Wellcome Trust through a grant to PJ and an Advanced Training Fellowship to MAA (ref: 064271/Z/01/Z). Conflict of interest: none declared.

Correspondence to: $\operatorname{Dr} M$ A Aldred, Division of Medical Genetics, Adrian Building, University of Leicester, University Road, Leicester LE1 7RH, UK; maldred@hgmp.mrc.ac.uk

Received 4 December 2003

Accepted for publication 3 February 2004

\section{REFERENCES}

1 Phelan MC, Rogers RC, Clarkson KB, Bowyer FP, Levine MA, Estabrooks LL, Severson MC, Dobyns WB. Albright hereditary osteodystrophy and del(2)(q37.3) in four unrelated individuals. Am J Med Genet 1995; 58: 1-7.

2 Wilson LC, Leverton K, Oude Luttikhuis MEM, Oley CA, Flint J, Wolstenholme J, Duckett DP, Barrow MA, Leonard JV, Read AP, Trembath RC. Brachydactyly and mental retardation: an Albright hereditary osteodystrophylike syndrome localised to 2q37. Am J Hum Genet 1995;56:400-7.

3 Haag M, Gilfillan T, Berry R, Hull C, Stewart J, Manchester DK, McGavran L. Microdeletion in chromosome 2qter in two unrelated children with characteristic facies and mental retardation. Am J Hum Genet 1993:53:A1571.

4 Power MM, James RS, Barber JCK, Fisher AM, Wood PJ, Leatherdale BA, Flanagan DEH, Hatchwell E. RDC1, the vasoactive intestinal peptide receptor: a candidate gene for the features of Albright hereditary osteodystrophy associated with deletion of 2q37. J Med Genet 1997;34:287-90.

5 Friedman BD, Gorski JL, Hall BD, Brothman A, Carey JC, Arbor WL. Deletion of chromosomal region 2q37: clinical phenotype in eight cases. Am J Hum Genet 1997;61:A545.

6 Viot-Szoboszlai G, Amiel J, Doz F, Prieur M, Couturier J, Zucker JN, Henry I, Munnich A, Vekemans M, Lyonnet S. Wilms' tumor and gonadal dysgenesis in a child with the 2q37.1 deletion syndrome. Clin Genet 1998:53:278-80

7 Bijlsma EK, Aalfs CM, Sluijter S, Oude Luttikhuis MEM, Trembath RC, Hoovers JMN, Hennekam RCM. Familial cryptic translocation between chromosomes 2qter and 8qter: further delineation of the Albright hereditary osteodystrophy-like phenotype. J Med Genet 1999;36:604-9.

8 Braddock BR, Shrimpton AE, Stein CS, Hoo JJ. Two distinctively different phenotypes of $2 q 37$ terminal deletion: location of a gene on telomeric $2 q 37$ mimicking Albright hereditary osteodystrophy/pseudohypoparathyroidism. Am J Hum Genet 1999;65:A861

9 Reddy KS, Flannery D, Farrer RJ. Microdeletion of chromosome sub-band $2 q 37.3$ in two patients with abnormal situs visceram. Am J Med Genet 1999;84:460-8

10 Smith M, Escamilla JR, Filipek P, Bocian ME, Modahl C, Flodman P, Spence MA. Molecular genetic delineation of $2 q 37.3$ deletion in autism and osteodystrophy: report of a case and of new markers for deletion screening by PCR. Cytogenet Cell Genet $2001 ; 94: 15-22$.

11 Rio M, Molinari F, Heuertz S, Ozilou C, Gosset P, Raoul O, Cormier-Daire V Amiel J, Lyonnet $S$, Le Merrer M, Turleau C, de Blois MC, Prieur M, Romana S, Vekemans $M$, Munnich A, Colleaux L. Automated fluorescent genotyping detects $10 \%$ of cryptic subtelomeric rearrangements in idiopathic syndromic mental retardation. J Med Genet 2002;39:266-70.

12 Syrrou M, Keymolen K, Devriendt K, Holvoet M, Thoelen R, Verhofstadt K, Fryns J-P. Glypican 1 gene: good candidate for brachydactyly type $\mathrm{E}$. Am J Med Genet 2002;108:310-4.

13 Weise A, Starke H, Heller A, Tonnies H, Volleth M, Stumm M, Gabriele S, Nietzel A, Claussen U, Liehr T. Chromosome 2 aberrations in clinical cases characterised by high resolution multicolour banding and region specific FISH probes. J Med Genet 2002;39:434-9.

14 Batstone PJ, Simpson S, Bonthron DT, Keng WT, Hamilton D, Forsyth L, Sales M, Pratt N, Goudie D. Effective monosomy or trisomy of chromosome band $2 q 37.3$ due to the unbalanced segregation of a $2 ; 11$ translocation. Am J Med Genet 2003;118A:241-6

15 Giardino D, Finelli P, Gottardi G, De Canal G, Monica MD, Lonardo F Scarano G, Larizza L. Narrowing the candidate region of Albright hereditary osteodystrophy-like syndrome by deletion mapping in a patient with an unbalanced cryptic translocation $\mathrm{t}(2 ; 6)(\mathrm{q} 37.3 ; \mathrm{q} 26)$. Am J Med Genet 2003; 122A: 261-5.

16 Fisher AM, Ellis KH, Browne CE, Barber JCK, Barker M, Kennedy CR, Foley H Patton MA. Small terminal deletions of the long arm of chromosome 2: two new cases. Am J Med Genet 1994;53:366-9.

17 Wang TH, Johnston K, Hsieh CL, Dennery PA. Terminal deletion of the long arm of chromosome 2 in a premature infant with karyotype: 46,XY, del(2)(q37). Am J Med Genet 1994;49:399-401.

18 Stratton RF, Tolworthy JA, Young RS. Deletion (2)(q37). Am J Med Genet 1994:51:153-5.

19 Conrad B, Dewald G, Christensen E, Lopez M, Higgins J, Pierpoint ME. Clinical phenotype associated with terminal 2q37 deletion. Clin Genet 1995;48: 134-9.
20 Ardinger $\mathrm{HH}$, Persons DL, Lutz RE, Beattie MA. Significant hypotonia and developmental delay: hallmarks of a terminal deletion of chromosome $2 q$ Am J Hum Genet 1999;65:A853.

21 Giardino D, Finelli P, Gottardi G, Clerici D, Mosca F, Briscioli V, Larizza L. Cryptic subtelomeric translocation $\mathrm{t}(2 ; 16)(\mathrm{q} 37 ; \mathrm{q} 24)$ segregating in a family with unexplained stillbirths and a dysmorphic, slightly retarded child. Eur J Hum Genet $2001 ; 9: 881-6$

22 Temple IK, Browne C, Hodgkins P. Anterior chamber eye anomalies, redundant skin and syndactyly-a new syndrome associated with breakpoints at 2q37.2 and 7q36.3. Clin Dysmorphol 1999;8:157-63.

23 Ghaffari SR, Boyd E, Tolmie JL, Crow YJ, Trainer AH, Connor JM. A new strategy for cryptic telomeric translocation screening in patients with idiopathic mental retardation. J Med Genet 1998;35:225-33.

24 Bruyere H, Rajcan-Separovic E, Doyle J, Pantzar T, Langlois S. Familial cryptic translocation $(2 ; 17)$ ascertained through recurrent spontaneous abortions. Am J Med Genet 2003;123A:285-9.

25 Stein CK, Del Signore C, Bellinger M, Bryke CR. Deletion of 2q37-a new syndrome? Am J Hum Genet 1992;51:A1223.

26 Bonaglia MC, Giorda R, Poggi G, Raggi ME, Rossi E, Baroncini A, Giglio S, Borgatti $R$, Zuffardi $O$. Inverted duplications are recurrent rearrangements always associated with a distal deletion: description of a new case involving 2q. Eur J Hum Genet 2000;8:597-603.

27 Bacino CA, Kashork CD, Davino NA, Shaffer LG. Detection of a cryptic translocation in a family with mental retardation using FISH and telomere region-specific probes. Am J Med Genet 2000;92:250-5.

28 Gorski JL, Cox BA, Kyine M, Uhlmann W, Glover TW. Terminal deletion of the long arm of chromosome 2 in a mildly dysmorphic hypotonic infant with karyotype 46,XY, del(2)(q37). Am J Med Genet 1989;32:350-2.

29 Daniel A, Baker E, Chia N, Haan E, Malafiej P, Hinton L, Clarke N, Ades L, Darmanian A, Callen D. Recombinants of intrachromosomal transposition of subtelomeres in chromosomes 1 and 2: a cause of minute terminal chromosomal imbalances. Am J Med Genet 2003;117A:57-64.

30 Burd L, Martsolf JT, Kerbeshian J, Jalal SM. Partial 6p trisomy associated with infantile autism. Clin Genet 1988:33:356-9.

31 Speleman F, Callens B, Logghe K, Van Roy N, Horsley SW, Jauch A, Verschraegen-Spae MR, Leroy JG. Subtelomeric familial translocation $\dagger(2 ; 7)(q 37 ; q 35)$ leading to partial trisomy 7q35 $\rightarrow$ qter: molecular cytogenetic analysis and clinical phenotype in two generations. Am J Med Genet 2000;93:349-54.

32 Wolff DJ, Clifton K, Karr C, Charles J. Pilot assessment of the subtelomeric regions of children with autism: detection of a $2 q$ deletion. Genet Med 2002;4:10-4

33 Lehman NL, Zaleski DH, Sanger WG, Adickes E, eds. Holoprosencephaly associated with an apparent isolated $2 q 37.1 \rightarrow 2 q 37.3$ deletion. Am J Med Genet 2001;100:179-81.

34 Armour JA, Sismani C, Patsalis PC, Cross G. Measurement of locus copy number by hybridisation with amplifiable probes. Nucleic Acids Res 2000;28:605-9.

35 White $S$, Kalf $M$, Liu $Q$, Villerius $M$, Engelsma $D$, Kriek $M$, Vollebregt $E$, Bakker B, van Ommen GJ, Breuning MH, den Dunnen JT. Comprehensive detection of genomic duplications and deletions in the DMD gene, by use of multiplex amplifiable probe hybridization. Am J Hum Genet 2002;71:365-74

36 Benson $\mathbf{G}$. Tandem repeats finder: a program to analyze DNA sequences. Nucleic Acids Res 1999;27:573-80.

37 Knight SJ, Lese CM, Precht KS, Kuc J, Ning Y, Lucas S, Regan R, Brenan M, Nicod A, Lawrie NM, Cardy DL, Nguyen H, Hudson TJ, Riethman HC Ledbetter DH, Flint J. An optimized set of human telomere clones for studying telomere integrity and architecture. Am J Hum Genet 2000;67:320-32.

38 Ballif BC, Kashork CD, Shaffer LG. The promise and piffalls of telomere region-specific probes. Am J Hum Genet 2000;67:1356-9.

39 Nickerson E, Greenberg F, Keating MT, McCaskill C, Shaffer LG. Deletions of the elastin gene at $7 q 11.23$ occur in approximately $90 \%$ of patients with Williams syndrome. Am J Hum Genet 1995;56:1156-61.

40 Baumer A, Dutly F, Balmer D, Riegel M, Tukel T, Krajewska-Walasek M, Schinzel AA. High level of unequal meiotic crossovers at the origin of the 22q11. 2 and 7q11.23 deletions. Hum Mol Genet 1998;7:887-94.

41 Schaub RL, Reveles XT, Baillargeon J, Leach RJ, Cody JD. Molecular characterization of 18p deletions: evidence for a breakpoint cluster. Genet Med 2002;4:15-9.

42 Cody JD, Pierce JF, Brkanac Z, Plaetke R, Ghidoni PD, Kaye Cl, Leach RJ. Preferential loss of the paternal alleles in the 18q- syndrome. Am J Med Genet 1997:69:280-6.

43 Wieczorek D, Krause M, Majewski F, Albrecht B, Horn D, Riess O, GillessenKaesbach $G$. Effect of the size of the deletion and clinical manifestation in Wolf-Hirschhorn syndrome: analysis of 13 patients with a de novo deletion. Eur J Hum Genet 2000;8:519-26.

44 Mainardi PC, Perfumo C, Cali A, Coucourde G, Pastore G, Cavani S, Zara F, Overhauser J, Pierluigi $M$, Bricarelli FD. Clinical and molecular characterisation of 80 patients with $5 p$ deletion: genotype-phenotype correlation. J Med Genet 2001;38:151-8.

45 Miyake N, Kurotaki N, Sugawara H, Shimokawa O, Harada N, Kondoh T, Tsukahara M, Ishikiriyama S, Sonoda T, Miyoshi Y, Sakazume S, Fukushima Y, Ohashi H, Nagai T, Kawame H, Kurosawa K, Touyama M, Shiihara T, Okamoto N, Nishimoto J, Yoshiura K, Ohta T, Kishino T, Niikawa N, Matsumoto N. Preferential paternal origin of microdeletions caused by prezygotic chromosome or chromatid rearrangements in Sotos syndrome. Am J Hum Genet 2003;72:1331-7.

46 Heilstedt HA, Ballif BC, Howard LA, Lewis RA, Stal S, Kashork CD, Bacino CA, Shapira SK, Shaffer LG. Physical map of 1p36, placement of breakpoints in 
monosomy $1 \mathrm{p} 36$, and clinical characterization of the syndrome. Am J Hum Genet 2003;72:1200-12.

47 Zollino M, Lecce R, Fischetto R, Murdolo M, Faravelli F, Selicorni A, Butte C, Memo L, Capovilla G, Neri G. Mapping the Wolf-Hirschhorn syndrome phenotype outside the currently accepted WHS critical region and defining a new critical region, WHSCR-2. Am J Hum Genet 2003;72:590-7.

48 Endele S, Fuhry M, Pak SJ, Zabel BU, Winterpacht A. LETM1, a novel gene encoding a putative EF-hand $\mathrm{Ca}(2+)$-binding protein, flanks the WolfHirschhorn syndrome (WHS) critical region and is deleted in most WHS patients. Genomics 1999:60:218-25.

49 Green EK, Priestley MD, Waters J, Maliszewska C, Latif F, Maher ER. Detailed mapping of a congenital heart disease gene in chromosome 3p25. J Med Genet 2000;37:581-7.

50 Robinson SW, Morris CD, Goldmuntz E, Reller MD, Jones MA, Steiner RD, Maslen CL. Missense mutations in CRELDI are associated with cardiac atrioventricular septal defects. Am J Hum Genet 2003;72:1047-52.

51 Gao B, Guo J, She C, Shu A, Yang M, Tan Z, Yang X, Guo S, Feng G, He L. Mutations in $\mathrm{IHH}$, encoding Indian hedgehog, cause brachydactyly type A-1. Nat Genet $2001 ; 28: 386-8$.

52 Davids MS, Crawford E, Weremowicz S, Morton CC, Copeland NG Gilbert DJ, Jenkins NA, Phelan MC, Comb MJ, Melnick MB. STK25 is a candidate gene for pseudopseudohypoparathyroidism. Genomics $2001 ; 77: 2-4$

53 Lee MS, Lowe G, Flanagan S, Kuchler K, Glackin CA. Human Dermo-1 has attributes similar to twist in early bone development. Bone 2000;27:591-602.

54 Yonan AL, Alarcon M, Cheng R, Magnusson PK, Spence SJ, Palmer AA, Grunn A, Juo SH, Terwilliger JD, Liu J, Cantor RM, Geschwind DH, Gilliam TC. A genome wide screen of 345 families for autism-susceptibility loci. Am J Hum Genet 2003:73:886-97.

55 Stalmans I, Lambrechts D, De Smet F, Jansen S, Wang J, Maity S, Kneer P, von $\operatorname{der}$ Ohe M, Swillen A, Maes C, Gewillig M, Molin DG, Hellings P,
Boetel T, Haardt M, Compernolle V, Dewerchin M, Plaisance S, Vlietinck R, Emanuel B, Gittenberger-de Groot AC, Scambler P, Morrow B, Driscol DA, Moons L, Esguerra CV, Carmeliet G, Behn-Krappa A, Devriendt K, Collen D, Conway SJ, Carmeliet P. VEGF: a modifier of the del22q11 (DiGeorge) syndrome? Nat Med 2003;9:173-82.

56 Ming JE, Muenke M. Multiple hits during early embryonic development: digenic diseases and holoprosencephaly. Am J Hum Genet 2002;71:1017-32.

57 Ji Y, Eichler EE, Schwartz S, Nicholls RD. Structure of chromosomal duplicons and their role in mediating human genomic disorders. Genome Res 2000; 10:597-610.

58 Osborne LR, Li M, Pober B, Chitayat D, Bodurtha J, Mandel A, Costa T, Grebe T, Cox S, Tsui LC, Scherer SW. A 1.5 million-base pair inversion polymorphism in families with Williams-Beuren syndrome. Nat Genet 2001;29:321-5.

59 Stankiewicz P, Lupski JR. Molecular-evolutionary mechanisms for genomic disorders. Curr Opin Genet Dev 2002;12:312-9.

60 Giglio S, Broman KW, Matsumoto N, Calvari V, Gimelli G, Neumann T, Ohashi H, Voullaire L, Larizza D, Giorda R, Weber JL, Ledbetter DH, Zuffardi $O$. Olfactory receptor-gene clusters, genomic-inversion polymorphisms, and common chromosome rearrangements. Am J Hum Genet 2001;68:874-83.

61 Giglio S, Calvari V, Gregato G, Gimelli G, Camanini S, Giorda R, Ragusa A, Guerneri S, Selicorni A, Stumm M, Tonnies H, Ventura M, Zollino M, Neri G, Barber J, Wieczorek D, Rocchi M, Zuffardi O. Heterozygous submicroscopic inversions involving olfactory receptor-gene clusters mediate the recurrent $t(4 ; 8)($ p 16;p23) translocation. Am J Hum Genet 2002;71:276-85.

62 Schwartz S, Astbury C, Bailey J, Crowe C, Eichler EE, Eichenmiller M, Graf $M$. Delineation of genomic breakpoints in chromosomal rearrangements: lack of involvement of duplicated segments. Am J Hum Genet 2003;73:A206. 